\title{
PEMBELAJARAN FISIKA MODEL PROBLEM BASED LEARNING MELALUI MEDIA ANIMASI DAN MODUL INTERAKTIF DITINJAU DARI KEMAMPUAN AWAL DAN GAYA BELAJAR SISWA
}

\author{
Sri Setyabudi ${ }^{1}$, Widha Sunarno ${ }^{2}$, Sukarmin $^{3}$ \\ ${ }^{1}$ Guru Fisika SMA Negeri 2 Sukoharjo \\ jocelynangelina@yahoo.co.id \\ ${ }^{2}$ Dosen Program Studi Pendidikan Sains Program Pascasarjana Universitas Sebelas Maret \\ widhasunarno@gmail.com \\ ${ }^{3}$ Dosen Program Studi Pendidikan Sains Program Pascasarjana Universitas Sebelas Maret \\ karmin.abdulkarim@gmail.com
}

\begin{abstract}
ABSTRAK
Tujuan penelitian ini adalah untuk mengetahui pengaruh pembelajaran fisika model problem based learning dengan menggunakan media animasi dan modul interaktif, kemampuan awal, gaya belajar dan interaksinya terhadap prestasi belajar siswa. Penelitian ini menggunakan media animasi dan modul interaktif dalam pembelajaran fisika. Populasinya terdiri dari siswa kelas X SMAN 2 Sukoharjo tahun pelajaran 2012/2013. Sampel terdiri dari 2 kelas yaitu Kelas X6 dan X7 yang diambil dengan menggunakan teknik cluster random sampling. Teknik pengumpulan data prestasi kognitif dan kemampuan awal digunakan metode tes. Untuk data gaya belajar digunakan metode angket. Teknik analisis data menggunakan analisis variansi tiga jalan desain faktorial $2 \times 2 \times 2$ dengan sel tak sama. Berdasarkan hasil penelitian dapat disimpulkan: 1) tidak terdapat pengaruh pembelajaran model problem based learning menggunakan media animasi dan modul interaktif terhadap prestasi belajar kognitif; 2) terdapat pengaruh kemampuan awal tinggi dan rendah terhadap prestasi kognitif; 3) terdapat pengaruh gaya belajar visual dan auditorial terhadap prestasi kognitif; 4) tidak terdapat interaksi pembelajaran model problem based learning menggunakan media animasi dan modul interaktif dengan kemampuan awal terhadap prestasi kognitif; 5) tidak terdapat interaksi pembelajaran model problem based learning menggunakan media animasi dan modul interaktif dengan gaya belajar terhadap prestasi kognitif; 6) tidak terdapat interaksi antara kemampuan awal dan gaya belajar terhadap prestasi kognitif; 7) tidak terdapat interaksi pembelajaran model problem based learning menggunakan media animasi dan modul interaktif, kemampuan awal, dan gaya belajar terhadap prestasi kognitif.
\end{abstract}

Kata kunci : problem based learning, media animasi, dan media modul interaktif.

\section{Pendahuluan}

Perkembangan di dunia pendidikan mengajarkan segenap insan untuk memecahkan masalah yang menjadi tanggung jawabnya sebagai warga negara Indonesia. Pendidikan di atur oleh suatu sistem yaitu sistem pendidikan nasional. Menurut UU No. 20 Tahun 2003 Pasal 5 yang berisi dua ayat yaitu: (1) setiap warga Negara mempunyai hak yang sama untuk memperoleh pendidikan yang bermutu; dan ayat (5) setiap warga negara berhak mendapatkan kesempatan meningkatkan pendidikan sepanjang hayat. Dari kedua ayat tersebut telah jelas bahwa setiap warga negara berhak mendapatkan pendidikan yang bermutu dan mempunyai kesempatan untuk mengembangkan dan meningkatkan pendidikan yang di miliki seumur hidupnya (long life education). 
Kurikulum yang dipakai saat ini adalah kurikulum 2006 dan setiap sekolah mengembangkan kurikulumnya secara mandiri yang disebut dengan kurikulum tingkat satuan pendidikan (KTSP). Hal ini merupakan tujuan pendidikan nasional yang meliputi kesesuaian dengan kekhasannya di lingkungan sekolah, kondisi dan potensi dari suatu daerah, serta satuan pendidikan dan siswa. Oleh karena itu, KTSP yang disusun oleh satuan pendidikan memungkinkan untuk menyesuaikan program pendidikan dengan kebutuhan dan potensi yang ada di daerah (BSNP 2006:1).

Setiap sekolah berhak memberikan pendekatan pembelajaran yang menarik dan menyenangkan bagi siswa. Untuk mencapai tujuan tersebut pembelajaran yang banyak dilakukan saat ini adalah pembelajaran yang monoton (konvensional). Setiap pelajaran disajikan dengan satu model pembelajaran yang monoton yaitu ceramah, terlebih jika guru tidak mengenalkan analog-analog atau alat peraga untuk memperjelas keterangannya. Ceramah dalam kelas akan memicu kebosanan, sehingga 15 menit setelah pelajaran tersebut dimulai konsentrasi para siswa mulai terganggu.

Usia sekolah merupakan usia siswa menyukai sesuatu yang baru yang dapat merangsang rasa ingin tahunya. Karena model pembelajaran yang digunakan saat ini belum cukup untuk membangkitkan antusias dan keaktifan siswa, maka dilakukan inovasi model pembelajaran yang lebih menyenangkan bagi siswa. Keadaan siswa yang menyenangkan adalah kunci seorang siswa dapat membangun ikatan emosional yaitu dengan menciptakan kesenangan dalam belajar, menjalin hubungan dan menyingkirkan segala ancaman dari suasana belajar (Bobbi dePorter 1999: 54). Penciptaan kegembiraan dalam belajar dapat membangkitkan keinginan siswa untuk belajar. Dengan kegembiraan tersebut, siswa dapat menerima pelajaran secara maksimal, terlebih pada pelajaran fisika. Pembelajaran adalah pengembangan pengetahuan, keterampilan atau sikap baru pada saat individu berinteraksi dengan informasi dan lingkungan. Berhasil atau tidaknya pembelajaran sangat bergantung pada guru, siswa dan sarana yang tersedia.

Faktor guru sangat berpengaruh terhadap keberlangsungan proses pembelajaran. Guru dituntut untuk melaksanakan tugasnya dengan profesional. Guru yang profesional dituntut untuk memiliki empat kompetensi yaitu: kompetensi paedagogik, kompetensi kepribadian, kompetensi sosial, dan kompetensi profesional. Supaya proses pembelajaran di sekolah berhasil, langkah yang diambil guru yang profesional adalah menentukan tindakan dalam memilih strategi pengajaran. Strategi pengajaran dapat menggunakan metode dan pendekatan tertentu yang sesuai dengan keadaan kelas dan topik materi pembelajaran.

Pembelajaran mata pelajaran fisika di setiap jenjang pendidikan merupakan salah satu upaya untuk meningkatkan kemampuan siswa agar mampu mengimplementasikan ilmu yang diperolehnya dengan baik. Tingkat penguasaan siswa terhadap ilmu fisika dipengaruhi oleh banyak faktor. Dari berbagai penelitian banyak faktor yang berpengaruh terhadap tingkat keberhasilan siswa secara garis besar dibedakan menjadi dua macam yaitu faktor internal (faktor dari dalam) yang meliputi minat, intelegensi, motivasi, gaya belajar, pengetahuan dasar, sikap ilmiah, bakat, minat dan sebagainya, dan faktor eksternal (faktor dari luar) antara lain kurikulum, sarana prasarana, media, sumber belajar, metode pembelajaran, suasana keluarga, lingkungan sekolah, status sosial, interaksi dengan guru dan sebagainya.

Pembelajaran Fisika agar menarik diperlukan media yang benar-benar efektif dan efisien. Media yang efektif adalah yang mampu untuk mengkomunikasikan sesuatu yang ingin disampaikan. Guru dapat merancang sendiri media itu atau dibantu oleh ahli media, dapat juga membeli media karya orang lain. Sudah banyak sekolah 
yang memiliki perangkat keras seperti OHP, radio, VCD player, proyektor, slide, film dan komputer. Namun belum semua guru di sekolah tersebut dapat memanfaatkannya. Menurut Kukuh Santosa (2002) "meningkatkan kemampuan guru dalam merancang media jauh lebih mudah daripada menyuruh seorang ahli media untuk menjadi guru".

Orientasi pembelajaran fisika perlu lebih ditujukan kepada peran aktif siswa untuk belajar, dan guru hanya sebagai fasilitator pembelajaran. Hal ini berarti harus ada pergeseran paradigma pembelajaran fisika, yakni dari yang semula guru menetapkan apa yang akan dipelajari menjadi bagaimana menyediakan dan memperkaya pengalaman siswa. Pembelajaran fisika yang terjadi selama ini masih bersifat teacher centered dan belum berorientasi pada student centered. Guru kurang memberi ruang kepada siswa untuk ikut serta aktif dalam mengemukakan pendapat. Akibatnya, siswa menjadi pasif dan kurang termotivasi untuk belajar fisika sehingga bagi sebagian siswa, fisika masih dianggap sebagai pelajaran yang sulit dan membosankan.

Berdasarkan uraian di atas, dapat dibuat konklusi bahwa untuk membelajarkan fisika sesuai dengan hakikat fisika yang sesungguhnya - yang meliputi proses, produk, dan sikap - maka diperlukan pendekatan pembelajaran yang inovatif, dan kreatif. Pendekatan pembelajaran yang inovatif dan kreatif mampu membelajarkan siswa cara memperoleh pengetahuan, bukan hanya menerima pengetahuan. Ada beberapa pendekatan pembelajaran fisika yang berorientasi pada proses. Pendekatan ini dapat digunakan oleh guru, antara lain: contextual teaching and learning, problem based learning, problem solving, inquiry, discovery, dll. Meskipun telah banyak pendekatan pembelajaran fisika yang berorientasi pada proses dan sikap, namun pendekatan ini belum banyak diterapkan oleh para guru untuk membelajarkan IPA, khususnya fisika.
Pendekatan dan metode pembelajaran fisika yang telah dijelaskan sebelumnya perlu lebih terfokus pada pemberian pengalaman belajar langsung kepada siswa. Guru sebagai fasilitator pembelajaran perlu menekankan pembelajaran bermakna bagi siswa. Jika penerapan pendekatan serta metode dalam pembelajaran fisika kurang tepat maka hal ini akan berakibat pada rendahnya prestasi belajar siswa, kurangnya motivasi siswa untuk mempelajari fisika, serta pembelajaran fisika menjadi tidak bermakna. Oleh karena itu, pemilihan pendekatan serta metode dalam pembelajaran fisika menjadi sesuatu yang sangat penting manakala tolok ukur keberhasilan pembelajaran tersebut kurang dapat menunjukkan hasil yang menggembirakan. Kenyataan yang terjadi, guru belum menggunakan model-model pembelajaran yang bervariatif dan inovatif sehingga masih terkesan konvensional dan monoton. Akibatnya, yang terjadi adalah prestasi belajar fisika siswa yang belum optimal dibandingkan dengan pelajaran yang lain. Hal tersebutlah yang akan menjadi perhatian serius dalam upaya meningkatkan prestasi belajar fisika siswa. Baik prestasi belajar kognitif yang berhubungan dengan pengetahuan dan pemahaman siswa, prestasi belajar afektif yang berkenaan dengan sikap dan kecakapan hidup seseorang, serta prestasi belajar psikomotor yang erat kaitannya dengan skill atau keterampilan seseorang. Ketiganya merupakan satu kesatuan hasil belajar yang tidak dapat dipisahkan dengan yang lainnya.

Inti dari teori belajar bermakna Ausubel adalah proses belajar akan mendatangkan hasil atau bermakna jika guru dalam menyajikan materi pelajaran yang baru dapat menghubungkannya dengan konsep relevan yang sudah ada dalam struktur kognitif siswa. Hal tersebut berhubungan erat dengan kemampuan awal yang dimiliki siswa sebelum mempelajari konsep yang baru. Dengan kata lain, untuk mempelajari topik tertentu, siswa harus 
mempunyai kemampuan awal tertentu juga. Hal inilah yang harus diperhatikan oleh para guru dalam memulai proses pembelajaran fisika di kelas.

Guru perlu memperhatikan kemampuan awal yang dimiliki oleh peserta didik. Tujuannya yaitu untuk mempersiapkan guru dalam menyusun rancangan proses pembelajaran yang sesuai dengan tingkat kebutuhan siswa. Dengan demikian, proses pembelajaran di kelas akan lebih bermakna. Kemampuan awal siswa sebelum mempelajari materi tertentu dapat berupa kemampuan menggunakan alat ukur fisika yang berkaitan dengan materi tersebut. Hal inilah yang belum banyak diperhatikan oleh para guru.

Teknologi komunikasi dan informasi merupakan suatu alat yang telah berkembang sedemikian rupa, sehingga mempengaruhi segenap kehidupan dalam berbagai bentuk media yang dapat disumbangkan untuk pembelajaran di sekolah yang dulunya media-media tersebut belum ada. Media yang dapat menarik perhatian siswa salah satunya berupa media elektronik, sehingga siswa dapat mengakses tanpa membawa tumpukan cetakan-cetakan tulisan yang sangat banyak. Kebanyakan media yang digunakan adalah media power point yang hanya memberikan visualisasi dari teori tersebut. Selain media power point, agar lebih menarik siswa disuguhkan media yang baru. Media ini dapat berupa CD Interaktif dan modul elektronik. Dengan kedua media ini siswa juga ikut mengoperasikan, jadi tidak hanya sebentuk visualisasi media saja, selain itu siswa juga dapat mengilustrasikan pola seperti apa yang mereka pelajari.

Mata pelajaran fisika merupakan rumpun dari Ilmu Pengetahuan Alam yang berpotensi meningkatkan kejenuhan pada siswa dalam mempelajarinya, jika para guru hanya menggunakan model pembelajaran yang monoton dan konvensional, serta medianya pun hanya sebatas papan tulis dan spidol saja. Pada umumnya, pembelajaran fisika mengacu kepada konsep meminta yaitu terlalu banyak tuntutan kepada siswa.
Teori yang terangkum dalam suatu bab terlalu banyak, sehingga siswa perlu di beri media yang menunjang pembelajaran mereka. Seperti halnya pada bab suhu dan kalor yang memuat banyak teori hafalan dan materi yang abstrak, siswa sulit membayangkan kejadian yang sesungguhnya, sebaiknya siswa diberikan beberapa media agar mereka mengetahui proses suhu, pemuaian, kalor dan perpindahan kalor dan contoh yang ada pada kehidupan sehari-hari yang berkaitan dengan pelajaran tersebut. Dengan demikian penggunaan model pembelajaran dan media yang menyenangkan bagi siswa diharapkan siswa dapat mencerna informasi secara utuh dan dapat mengingatnya tanpa ada tekanan, sehingga secara tidak langsung siswa dapat menggabungkan materi dengan kehidupan sehari-hari yang pernah dialami. Media ini diharapkan dapat memberikan output yang baik.

Siswa merupakan sekumpulan individu heterogen, sehingga mereka mempunyai beberapa kemampuan dalam belajar. Dalam pembelajaran fisika, gaya belajar siswa bermacam-macam. Banyak siswa yang hanya mengandalkan pendengarannya saja sudah dapat mengabstrakkan keterangan yang diterima dari guru, ada pula yang membutuhkan tiruan benda asli atau media untuk dapat membantu pemahamannya. Materi suhu dan kalor membutuhkan kepahaman yang abstrak, karena siswa diharapkan dapat mengimajinasikan arah pemuaian, proses pertukaran kalor dan perpindahan kalor. Oleh karena, itu siswa yang heterogen tersebut mempunyai gaya belajar yang juga berbeda-beda. Gaya belajar setiap inidividu berbeda-beda dan semua gaya juga sama baiknya. Setiap individu mempunyai ketiga gaya belajar yaitu: audiovisual/auditorial, visual, kinestetik. Tetapi setiap individu juga mempunyai salah satu yang menonjol diantara ketiganya. Oleh karena itu, gaya belajar sangat berpengaruh terhadap input pembelajaran yang disampaikan oleh seorang guru. 
Cara untuk mengatasi masalah pembelajaran yang kompleks, diperlukan suatu pendekatan dan metode pembelajaran yang mampu mengatasi, minimal dapat mengurangi, masalah pembelajaran yang ada. Salah satu pendekatan pembelajaran yang dapat digunakan adalah problem based learning (PBL). PBL merupakan salah satu pembelajaran inovatif yang dapat memberikan kondisi belajar aktif kepada siswa. PBL melalui media animasi dan modul interaktif lebih berpusat pada siswa dan memberi kesempatan kepada siswa untuk terlibat secara langsung dalam proses: mengamati, menafsirkan pengamatan, meramalkan, menggunakan alat dan bahan, menemukan konsep, merencanakan penelitian, berkomunikasi dan mengajukan pertanyaan. Melalui PBL diharapkan prestasi belajar fisika siswa dapat lebih baik dan meningkat.

Materi Suhu dan Kalor merupakan salah satu materi fisika yang bersifat konkret dan abstrak Materi yang bersifat konkret dapat diamati secara langsung melalui percobaan, dan yang bersifat abstrak dapat dilihat melalui animasi maupun modul interaktif. Tujuannya agar siswa sendiri yang membangun konsep tentang materi tersebut dari interaksinya terhadap objek dan lingkungan dan siswa juga diharapkan mampu mengaplikasikan yang telah diperolehnya dalam kehidupan sehari-hari. Dengan demikian, hasil belajar yang dicapai tentunya dapat lebih bermakna dan siswa mempunyai tujuan yang nyata dalam mengikuti pembelajaran.

Berdasarkan uraian diatas maka akan dilakukan penelitian menerapkan pembelajaran Fisika model problem based learning melalui media animasi dan modul interaktif ditinjau dari kemampuan awal dan gaya belajar siswa. Adapun tujuan dalam penelitian ini adalah untuk mengetahui: (1) pengaruh penggunaan model problem based learning melalui media animasi dan modul interaktif terhadap prestasi belajar fisika siswa; (2) pengaruh kemampuan awal kategori tinggi dan kemampuan awal kategori rendah terhadap prestasi belajar fisika siswa; (3) pengaruh gaya belajar visual dan auditorial terhadap prestasi belajar fisika siswa; (4) interaksi pengaruh antara media pembelajaran dengan kemampuan awal terhadap prestasi belajar fisika siswa; (5) interaksi pengaruh antara media pembelajaran dengan gaya belajar siswa terhadap prestasi belajar fisika siswa; (6) interaksi pengaruh antara kemampuan awal dengan gaya belajar siswa terhadap prestasi belajar fisika siswa; (7) interaksi pengaruh antara media pembelajaran dengan kemampuan awal dan gaya belajar siswa terhadap prestasi belajar fisika siswa.

\section{Metodelogi Penelitian}

Penelitian ini dilaksanakan di SMA Negeri 2 Sukoharjo yang beralamat di Jl. Raya Solo-Kartasura, Mendungan, Pabelan, Kartasura. Waktu pelaksanaannya pada semester 2 tahun pelajaran 2012/2013. Waktu pelaksanaan penelitian ini mulai dari penyusunan proposal hingga pembuatan laporan penelitian dimulai bulan September tahun 2012 sampai dengan tahun Juli 2013. Penelitian ini adalah penelitian eksperimen. Kelompok eksperimen I diajar dengan model problem based learning melalui media animasi dan kelompok eksperimen II dengan menggunakan model problem based learning melalui modul interaktif.

Rancangan penelitian dalam penelitian ini disusun sesuai dengan variabel-variabel yang terlibat. Variabelvariabel terlibat dalam penelitian ini merupakan cerminan dari data-data yang akan diperoleh setelah perlakuan terhadap sampel penelitian yang dilakukan. Data yang diperoleh kemudian dianalisis menggunakan uji anava. Teknik pengambilan sampel menggunakan teknik cluster random sampling. Sampel yang digunakan dalam penelitian ini ada 2 kelas, yaitu kelas X.6 sebagai kelas eksperimen pertama dengan model problem based learning melalui media animasi dan kelas X.7 sebagai kelas eksperimen kedua dengan model problem based learning melalui modul interaktif. 
Teknik pengumpulan data dalam penelitian ini menggunakan: (1) metode Tes untuk mengetahui prestasi belajar siswa dalam ranah kognitif dan kemampuan awal siswa; (2) metode angket digunakan untuk mengetahui, gaya belajar siswa siswa.

Instrumen pelaksanaan penelitian dalam penelitian ini berupa silabus, Rencana Pelaksanaan Pembelajaran (RPP) dan Lembar Kerja Siswa (LKS). Instrumen pengambilan data digunakan tes dan angket. Tes digunakan untuk mengukur prestasi belajar kognitif dan kemampuan awal siswa. Angket digunakan untuk mengetahui gaya belajar siswa.

Uji normalitas data menggunakan uji Shapiro-Wilk yang terdapat pada software SPSS 17. Dan uji homogenitas digunakan adalah test of homogeneity variances. Kemudian Pengujian hipotesis pada penelitian ini menggunakan uji anava dengan bantuan software SPSS 17 .

\section{Hasil Penelitian dan Pembahasan}

Deskripsi data untuk kedua kelas eksperimen tersebut dapat dilihat pada Tabel 1.

Tabel 1. Deskripsi Data Prestasi Belajar Kognitif Ditinjau dari Media Belajar

\begin{tabular}{cccccc}
\hline Kelompok & $\begin{array}{c}\text { Jumlah } \\
\text { Data }\end{array}$ & Maks & Min & $\begin{array}{c}\text { Rata- } \\
\text { rata }\end{array}$ & $\begin{array}{c}\text { Standar } \\
\text { Deviasi }\end{array}$ \\
\hline $\begin{array}{c}\text { PBL melalui } \\
\text { Animasi } \\
\text { PBL }\end{array}$ & 35 & 87 & 47 & 69,66 & 9,683 \\
$\begin{array}{c}\text { melaluiModul } \\
\text { Interaktif }\end{array}$ & 35 & 87 & 38 & 66,00 & 14,392 \\
\hline
\end{tabular}

Pada Tabel 1 diperlihatkan nilai ratarata prestasi belajar kognitif kelas dengan model PBL melalui media animasi lebih tinggi dan memiliki standar deviasi yang lebih kecil dibandingkan model PBL melalui media modul interaktif. Dengan standar deviasi yang kecil pada model PBL melalui media animasi menunjukkan bahwa data mengumpul. Data mengumpul menunjukkan data nilai siswa yang baik untuk prestasi belajar kognitif. Sedangkan standar deviasi yang besar pada model PBL melalui media modul interaktif menunjukkan data menyebar. Dengan demikian model PBL melalui media animasi menunjukkan nilai siswa lebih baik daripada model PBL melalui media modul interaktif.

Tabel 2. Deskripsi Data Prestasi Belajar Kognitif Ditinjau dari Kemampuan Awal

\begin{tabular}{cccccc}
\hline Kelompok & $\begin{array}{c}\text { Jumlah } \\
\text { Data }\end{array}$ & Maks & Min & $\begin{array}{c}\text { Rata- } \\
\text { rata }\end{array}$ & $\begin{array}{c}\text { Standar } \\
\text { Deviasi }\end{array}$ \\
\hline $\begin{array}{c}\text { Kemampuan } \\
\text { Awal }\end{array}$ & 43 & 87 & 69 & 75,77 & 5,042 \\
$\begin{array}{c}\text { Tinggi } \\
\text { Kemampuan } \\
\text { Awal } \\
\text { Rendah }\end{array}$ & 27 & 67 & 38 & 55,19 & 9,548 \\
& & & & & \\
\hline
\end{tabular}

Pada Tabel 2 diperlihatkan nilai ratarata prestasi belajar kognitif kemampuan awal tinggi lebih tinggi dan memiliki standar deviasi yang lebih kecil dibandingkan prestasi belajar kognitif kemampuan awal rendah. Dengan standar deviasi yang kecil pada kemampuan awal tinggi menunjukkan bahwa data mengumpul. Data mengumpul menunjukkan data nilai siswa yang baik untuk prestasi belajar kognitif. Sedangkan standar deviasi yang besar pada kemampuan awal rendah menunjukkan data menyebar. Dengan demikian prestasi belajar kognitif kemampuan awal tinggi menunjukkan nilai siswa lebih baik daripada prestasi belajar kognitif kemampuan awal rendah.

Tabel 3. Deskripsi Data Prestasi Belajar Kognitif Ditinjau dari Gaya Belajar

\begin{tabular}{cccccc}
\hline Kelompok & $\begin{array}{c}\text { Jumlah } \\
\text { Data }\end{array}$ & Maks & Min & $\begin{array}{c}\text { Rata- } \\
\text { rata }\end{array}$ & $\begin{array}{c}\text { Standar } \\
\text { Deviasi }\end{array}$ \\
\hline Gaya & 38 & 87 & 47 & 70,79 & 9,473 \\
Belajar & & & & & \\
Visual & & & & & \\
$\quad$ Gaya & 32 & 84 & 38 & 64,31 & 14,385 \\
Belajar & & & & & \\
Auditorial & & & & & \\
\hline
\end{tabular}

Pada Tabel 3 diperlihatkan nilai ratarata prestasi belajar kognitif gaya belajar visual lebih tinggi dan memiliki standar deviasi yang lebih kecil dibandingkan prestasi belajar kognitif gaya belajar auditorial. Dengan standar deviasi yang kecil pada gaya belajar visual menunjukkan bahwa data mengumpul. Data mengumpul menunjukkan data nilai siswa yang baik untuk prestasi belajar kognitif. Sedangkan 
standar deviasi yang besar pada gaya belajar auditorial menunjukkan data menyebar. Dengan demikian prestasi belajar kognitif gaya belajar visual menunjukkan nilai siswa lebih baik daripada prestasi belajar kognitif gaya belajar auditorial.

Uji hipotesis dalam penelitian ini menggunakan Uji ANAVA 3 jalan, Hasil uji hipotesis ditunjukkan dalam tabel 4:

Tabel 4. Tabulasi Data Hasil Uji Hipotesis

\begin{tabular}{|c|c|c|c|c|}
\hline No & Faktor & p-value & Signifikansi & Hasil Uji \\
\hline 1. & $\begin{array}{l}\text { Media } \\
\text { Pembelajaran }\end{array}$ & 0,763 & $0,763>0,05$ & $\begin{array}{l}\text { Tidak ada } \\
\text { Perbedaan } \\
\text { (tdk } \\
\text { berpengaruh) }\end{array}$ \\
\hline 2. & $\begin{array}{l}\text { Kemampuan } \\
\text { Awal }\end{array}$ & 0,000 & $0,000<0,05$ & $\begin{array}{l}\text { Ada } \\
\text { perbedaan } \\
\text { (berpengaruh) }\end{array}$ \\
\hline 3. & Gaya Belajar & 0,008 & $0,008<0,05$ & $\begin{array}{l}\text { Ada } \\
\text { perbedaan } \\
\text { (berpengaruh) }\end{array}$ \\
\hline 4. & $\begin{array}{l}\text { Media } \\
\text { Pembelajaran } \\
* \\
\text { Kemampuan } \\
\text { Awal }\end{array}$ & 0,298 & $0,298>0,05$ & $\begin{array}{l}\text { Tidak ada } \\
\text { Interaksi } \\
\text { (tdk } \\
\text { berpengaruh) }\end{array}$ \\
\hline 5. & $\begin{array}{l}\text { Media } \\
\text { Pembelajaran } \\
* \\
\text { Gaya Belajar }\end{array}$ & 0,236 & $0,236>0,05$ & $\begin{array}{l}\text { Tidak ada } \\
\text { Interaksi } \\
\text { (tdk } \\
\text { berpengaruh) }\end{array}$ \\
\hline 6. & $\begin{array}{l}\text { Kemampuan } \\
\text { Awal } \\
\text { * } \\
\text { Gaya Belajar }\end{array}$ & 0,132 & $0,132>0,05$ & $\begin{array}{l}\text { Tidak ada } \\
\text { Interaksi } \\
\text { (tdk } \\
\text { berpengaruh) }\end{array}$ \\
\hline 7. & $\begin{array}{l}\text { Media } \\
\text { Pembelajaran } \\
* \\
\text { Kemampuan } \\
\text { Awal } \\
* \\
\text { Gaya Belajar }\end{array}$ & 0,367 & $0,367>0,05$ & $\begin{array}{l}\text { Tidak ada } \\
\text { Interaksi } \\
\text { (tdk } \\
\text { berpengaruh) }\end{array}$ \\
\hline
\end{tabular}

Berdasarkan Tabel 4 dan kriteria pengujian hipotesis pada uraian di atas, maka kesimpulan dari pengujian hipotesis dalam penelitian ini adalah sebagai berikut:

1.Pengaruh penggunaan model problem based learning melalui media animasi dan modul interaktif terhadap prestasi belajar fisika siswa.

Keberhasilan model Pembelajaran Berdasarkan Masalah (Problem Based Learning) sangat tergantung pada ketersediaan sumber belajar bagi siswa, alat-alat untuk menguji jawaban atau dugaan. Menuntut adanya perlengkapan praktikum, memerlukan waktu yang cukup apalagi data harus diperoleh dari lapangan, serta kemampuan guru dalam mengangkat dan merumuskan masalah.

Penelitian ini menggunakan media animasi dan media modul interaktif. Pemanfaatan media yang tepat dapat menyebabkan siswa bersemangat, tertarik terhadap materi pelajaran dan menyebabkan suasana belajar lebih nyaman. Media dapat digunakan dalam proses belajar mengajar dengan dua cara yaitu sebagai alat bantu mengajar dan sebagai media belajar yang dapat digunakan sendiri oleh siswa. Efektifitas media ini tergantung dari guru yang menggunakannya. Media pembelajaran seharusnya dipilih secara sistematik agar dapat digunakan secara efektif dan efisien.

Hasil prestasi belajar kognitif dari penggunaan model problem based learning melalui media animasi dan modul interaktif tidak jauh berbeda, hal tersebut disebabkan karena tahapan-tahapan pada proses pembelajarannya yang tidak berbeda secara signifikan, kemudian media yang digunakan memiliki daya tarik yang sama siswa untuk termotivasi untuk belajar. Nilai rata-rata dari kedua kelas tidak menunjukkan perbedaan yang signifikan pada prestasi belajar kognitif.

2.Pengaruh kemampuan awal kategori tinggi dan kemampuan awal kategori rendah terhadap prestasi belajar fisika siswa.

Kemampuan awal merupakan hasil belajar yang didapat sebelum mendapat kemampuan yang lebih tinggi. Kemampuan awal siswa merupakan prasyarat untuk mengikuti pembelajaran sehingga dapat melaksanakan proses pembelajaran dengan baik. Kemampuan seseorang yang diperoleh dari pelatihan selama hidupnya, dan apa yang dibawa untuk menghadapi suatu pengalaman baru. Menurut Rebber (1988) dalam Muhibbin Syah (2006: 121) yang mengatakan bahwa "kemampuan awal prasyarat awal untuk mengetahui adanya perubahan". Kemampuan awal siswa dapat diukur melalui tes awal, interview, atau cara-cara lain yang cukup sederhana 
seperti melontarkan pertanyaan-pertanyaan secara acak dengan distribusi perwakilan siswa yang representatif.

Dari uraian tersebut, dapat disimpulkan bahwa kemampuan awal merupakan prasyarat yang harus dimiliki siswa sebelum memasuki pembelajaran materi pelajaran berikutnya yang lebih tinggi. Dalam penelitian ini, kemampuan awal siswa didapat dengan melakukan tes kemampuan awal materi Suhu dan Kalor, sebelum memperoleh pengajaran model problem based learning melalui media animasi dan media modul interaktif.

Hasil prestasi belajar kognitif dengan model problem based learning ditinjau dari kemampuan awal tinggi dan rendah terdapat perbedaan secara signifikan. Artinya siswa yang memiliki kemampuan awal tinggi memiliki prestasi belajar kognitif yang lebih baik dibandingkan siswa yang memiliki kemampuan awal rendah. Nilai rata-rata siswa yang memiliki kemampuan awal tinggi secara signifikan berbeda dengan siswa yang memiliki kemampuan awal rendah. Hal ini dapat terjadi karena siswa yang memiliki kemampuan awal yang tinggi lebih cepat memahami materi dibandingkan dengan siswa yang memiliki kemampuan awal yang rendah.

3.Pengaruh gaya belajar visual dan auditorial terhadap prestasi belajar fisika siswa.

Gaya belajar visual (visual learners) menitikberatkan pada ketajaman penglihatan. Artinya, bukti-bukti konkret harus diperlihatkan terlebih dahulu agar mereka paham Gaya belajar seperti ini mengandalkan penglihatan atau melihat dulu buktinya untuk kemudian bisa mempercayainya. Ada beberapa karakteristik yang khas bagai orang-orang yang menyukai gaya belajar visual ini. Pertama adalah kebutuhan melihat sesuatu (informasi/pelajaran) secara visual untuk mengetahuinya atau memahaminya, kedua memiliki kepekaan yang kuat terhadap warna, ketiga memiliki pemahaman yang cukup terhadap masalah artistik, keempat memiliki kesulitan dalam berdialog secara langsung, kelima terlalu reaktif terhadap suara, keenam sulit mengikuti anjuran secara lisan, ketujuh seringkali salah menginterpretasikan kata atau ucapan.

Gaya belajar Auditorial (Auditory Learners) mengandalkan pada pendengaran untuk bisa memahami dan mengingatnya. Karakteristik model belajar seperti ini benar-benar menempatkan pendengaran sebagai alat utama menyerap informasi atau pengetahuan. Artinya, kita harus mendengar, baru kemudian kita bisa mengingat dan memahami informasi itu. Karakter pertama orang yang memiliki gaya belajar ini adalah semua informasi hanya bisa diserap melalui pendengaran, kedua memiliki kesulitan untuk menyerap informasi dalam bentuk tulisan secara langsung, ketiga memiliki kesulitan menulis ataupun membaca.

Hasil prestasi belajar kognitif dengan model problem based learning ditinjau dari gaya belajar visual dan auditorial terdapat perbedaan secara signifikan. Artinya siswa yang memiliki gaya belajar visual memiliki prestasi belajar yang lebih baik dibandingkan siswa yang memiliki gaya belajar auditorial. Nilai rata-rata siswa yang memiliki gaya belajar visual secara signifikan berbeda dengan siswa yang memiliki gaya belajar auditorial. Hal ini dapat terjadi karena media animasi dan modul interaktif lebih banyak diminati dan mendekati ciri-ciri yang sesuai dengan yang dimiliki oleh siswa dengan gaya belajar visual.

Berdasarkan penjelasan diatas, dapat disimpulkan bahwa siswa yang memiliki gaya belajar visual memiliki prestasi belajar yang lebih baik dibandingkan dengan siswa yang memiliki gaya belajar auditorial pada aspek kognitif khususnya pada pembelajaran materi suhu dan kalor. 
4.Interaksi pengaruh antara media pembelajaran dengan kemampuan awal terhadap prestasi belajar fisika siswa.

Kemajuan ilmu pengetahuan dan teknologi khususnya dalam bidang komunikasi dan informasi, sangat berpengaruh pada penyusunan strategi pembelajaran. Dengan adanya media pembelajaran, proses pembelajaran akan lebih efektif dan menarik bagi siswa. Namun demikian, media bukan hanya berupa alat atau bahan saja, tetapi hal-hal lain memungkinkan siswa dapat memperoleh pengetahuan. Menurut Gerlach secara umum media itu meliputi orang, bahan, peralatan atau kegiatan yang menciptakan kondisi yang memungkinkan siswa untuk memperoleh pengetahuan, keterampilan, dan sikap.

Media yang dipakai dalam pembelajaran ini terdiri atas software dan hardware. Software adalah bahan-bahan informasi yang terdapat dalam sound, slide, kaset dan sebagainya. Hardware adalah segenap peralatan teknis yang memungkinkan software dapat dinikmati, seperti tape, proyektor, komputer dan sebagainya. Pengajaran melalui media audio visual adalah produksi dan penggunaan materi yang penyerapannya melalui pandangan dan pendengaran serta tidak seluruhnya tergantung kepada pemahaman kata atau simbol-simbol yang serupa.

Media berbasis visual (image atau perumpamaan) memegang peranan penting dalam proses pembelajaran. Media visual dapat memperlancar pemahaman dan memperkuat ingatan. Agar menjadi efektif, visual sebaiknya ditempatkan pada konteks yang bermakna dan siswa harus berinteraksi dengan visual (image) untuk meyakinkan proses terjadinya informasi (Azhar Arsyad, 2009: 91). Media animasi dan modul interaktif adalah media yang memiliki daya tarik bagi siswa untuk lebih termotivasi dalam belajar. Siswa yang memiliki kemampuan awal baik, mestinya akan lebih mudah memahami materi pelajaran melalui kedua jenis media pembelajaran ini.
Hasil penelitian ini, tidak ditemukan pengaruh bersama yang signifikan antara model problem based learning melalui media animasi dan modul interaktif dengan kemampuan awal terhadap prestasi kognitif. Pengaruh yang diberikan oleh model problem based learning melalui media animasi dan modul interaktif terhadap prestasi kognitif, merupakan pengaruh yang berdiri sendiri dan tidak berhubungan dengan kemampuan awal siswa. Begitu pula sebaliknya, pengaruh yang diberikan oleh kemampuan awal terhadap prestasi belajar kognitif merupakan pengaruh yang berdiri sendiri dan tidak berhubungan dengan model problem based learning melalui media animasi dan modul interaktif.

5.Interaksi pengaruh antara media pembelajaran dengan gaya belajar siswa terhadap prestasi belajar fisika siswa. Media berbasis visual (image atau perumpamaan) memegang peranan penting dalam proses pembelajaran. Media visual dapat memperlancar pemahaman dan memperkuat ingatan. Agar menjadi efektif, visual sebaiknya ditempatkan pada konteks yang bermakna dan siswa harus berinteraksi dengan visual (image) untuk meyakinkan proses terjadinya informasi (Azhar Arsyad, 2009: 91). Media animasi dan modul interaktif adalah media yang memiliki daya tarik bagi siswa untuk lebih termotivasi dalam belajar.

Setiap anak memiliki kemampuan yang berbeda-beda dalam menyerap ilmu pelajaran. Gaya belajar yang dimiliki anak akan menentukan seberapa besar anak menyerap materi yang disampaikan oleh sang pengajar. Kesamaan metode dalam penyampaian materi dengan gaya belajar anak akan lebih memaksimalkan dalam penyerapan dan pemahaman anak. Karena secara tidak langsung gaya belajar guru dan gaya belajar anak akan memiliki pola yang sama. Dalam penelitian ini, gaya belajar dikategorikan ke dalam gaya belajar visual dan auditorial. 
Ciri-ciri gaya belajar visual diantaranya adalah : a. anak akan berusaha untuk melihat wajah gurunya yang sedang menyampaikan materi. b. anak tidak suka menjadi terdepan dalam berbicara dan anak cenderung tidak suka menjelaskan penjelasan orang lain. c. anak tidak cepat dalam memahami pembelajaran yang disampaikan secara lisan. d. anak dapat berdiam diri dan tetap konsentrasi manakala lingkungannya banyak keributan dan ramai. e. ketika anak kesusahan dalam menyampaikan sesuatu, maka anak akan menggunakan gerakan tubuh untuk membantu dalam penyampaian. $f$. mementingkan penampilan. g. anak akan mudah mengingat apa yang dibacanya dan anak suka dengan membaca.

Ciri-ciri gaya belajar auditorial adalah sebagai berikut : a. anak lebih suka dengan pembelajaran dengan metode diskusi dan anak akan mampu untuk mengingat pelajaran yang disampaikan secara lisan. b. anak lebih senang bicara dan fasih dalam menyampaikan. c. anak akan mudah mengingat lirik lagu ataupun suara yang didengarnya. d. anak tidak pandai dalam membuat karangan maupun menulis. e. anak kesulitan mengingat apa yang telah dibacanya, dan anak suka membaca dengan keras. f. anak sulit berkonsentrasi saat terjadi kebisingan atau keributan.

Melihat ciri-ciri gaya belajat visual dan auditorial, dapat disimpulkan bahwa ciri-ciri kedua gaya belajar ini ada sebagian yang mendukung pembelajaran dengan media animasi dan modul interaktif, ada sebagian yang tidak mendukung.

Hasil penelitian ini, tidak ditemukan pengaruh bersama yang signifikan antara model problem based learning melalui media animasi dan modul interaktif dengan gaya belajar terhadap prestasi kognitif. Pengaruh yang diberikan oleh model problem based learning melalui media animasi dan modul interaktif terhadap prestasi kognitif, merupakan pengaruh yang berdiri sendiri dan tidak berhubungan dengan gaya belajar siswa. Begitu pula sebaliknya, pengaruh yang diberikan oleh gaya belajar terhadap prestasi belajar kognitif merupakan pengaruh yang berdiri sendiri dan tidak berhubungan dengan model problem based learning melalui media animasi dan modul interaktif.

6. Interaksi pengaruh antara kemampuan awal dengan gaya belajar siswa terhadap prestasi belajar fisika siswa.

$\begin{array}{cl}\text { Gagne dalam Nana Sudjana } \\ (2005: 158) & \text { menyatakan bahwa }\end{array}$ "kemampuan awal lebih rendah dari pada kemampuan baru dalam pembelajaran, kemampuan awal merupakan prasyarat yang harus dimiliki siswa sebelum memasuki pembelajaran materi pelajaran berikutnya yang lebih tinggi." Jadi seorang siswa yang mempunyai kemampuan awal yang baik akan lebih cepat memahami materi dibandingkan dengan siswa yang tidak mempunyai kemampuan awal dalam proses pembelajaran. Kemampuan awal juga bisa disebut dengan prior knowledge (PK).

Gaya belajar atau learning style adalah suatu karakteristik kognitif, afektif dan prilaku psikomotorik sebagai indikator yang bertindak relatif stabil untuk pembelajar merasa saling berhubungan dan bereaksi terhadap lingkungan belajar (Gobai, 2005:1). Gaya belajar adalah cara yang lebih kita sukai dalam melakukan kegiatan berfikir, memproses dan mengerti suatu informasi (Gunawan, 2006: 139). Dari definisi di atas, dapat disimpulkan bahwa gaya belajar adalah ciri khas yang dimiliki oleh setiap orang dalam memberikan respon terhadap pembelajaran yang diterimanya. Menurut Bendler dan Grinder, 1981 (dalam De Porter, 2000: 85): "Meskipun kebanyakan orang memiliki akses ketiga modalitas visual, auditorial dan kinestetik hampir semua orang cenderung pada satu modalitas belajar yang berperan sebagai saringan untuk pembelajaran, pemerosesan dan komunikasi”.

Hasil penelitian ini, tidak ditemukan pengaruh bersama yang signifikan antara kemampuan awal dengan gaya belajar terhadap prestasi kognitif. 
Pengaruh yang diberikan oleh kemampuan awal terhadap prestasi kognitif, merupakan pengaruh yang berdiri sendiri dan tidak berhubungan dengan gaya belajar siswa. Begitu pula sebaliknya, pengaruh yang diberikan oleh gaya belajar terhadap prestasi belajar kognitif merupakan pengaruh yang berdiri sendiri dan tidak berhubungan dengan kemampuan awal.

Hal ini dapat disimpulkan bahwa tidak terdapat interaksi antara kemampuan awal dengan gaya belajar terhadap prestasi kognitif siswa.

7. Interaksi pengaruh antara media pembelajaran dengan kemampuan awal dan gaya belajar siswa terhadap prestasi belajar fisika siswa.

Problem based learning adalah suatu pendekatan pembelajaran yang diawali dengan penyajian masalah yang dirancang dalam konteks yang relevan dengan materi yang dipelajari. Pembelajaran berbasis masalah menggunakan berbagi macam kecerdasan yang diperlukan untuk melakukan konfrontasi terhadap tantangan dunia nyata, kemampuan untuk menghadapi segala sesuatu yang baru dan kompleksitas yang ada (Tan,2000). Problem based learning dalam kaitannya dengan mata pelajaran fisika adalah suatu pendekatan pembelajaran yang diawali dengan menghadapkan siswa dalam masalah konsep fisika. Dengan segenap pengetahuan dan kemampuannya, siswa dituntut untuk menyelesaikan masalah yang kaya dengan konsep-konsep fisika.

Pemanfaatan media yang tepat dapat menyebabkan siswa bersemangat, tertarik terhadap materi pelajaran dan menyebabkan suasana belajar lebih nyaman. Media dapat digunakan dalam proses belajar mengajar dengan dua cara yaitu sebagai alat bantu mengajar dan sebagai media belajar yang dapat digunakan sendiri oleh siswa. Efektifitas media ini tergantung dari guru yang menggunakannya. Media pembelajaran seharusnya dipilih secara sistematik agar dapat digunakan secara efektif dan efisien.

Kemampuan awal siswa penting untuk diketahui guru sebelum ia mulai dengan pembelajarannya, karena dengan demikian dapat diketahui: a) apakah siswa telah mempunyai atau pengetahuan yang merupakan prasyarat (prerequisite) untuk mengikuti pembelajaran; b) sejauh mana siswa telah mengetahui materi apa yang akan disajikan. Dengan mengetahui kedua hal tersebut, guru akan dapat merancang pembelajaran dengan lebih baik, sebab apabila siswa diberi materi yang telah diketahui maka mereka akan merasa cepat bosan.

Gaya belajar dapat menentukan prestasi belajar anak. Jika diberikan strategi yang sesuai dengan gaya belajarnya, anak dapat berkembang dengan lebih baik. Gaya belajar otomatis tergantung dari orang yang belajar. Artinya, setiap orang mempunyai gaya belajar yang berbeda-beda.

Hasil penelitian ini, tidak ditemukan pengaruh bersama yang signifikan antara model problem based learning melalui media animasi dan modul interaktif, kemampuan awal, dan gaya belajar terhadap prestasi kognitif. Pengaruh yang diberikan oleh media animasi dan modul interaktif terhadap prestasi kognitif, merupakan pengaruh yang berdiri sendiri dan tidak berhubungan dengan kemampuan awal dan gaya belajar siswa. Begitu pula sebaliknya, pengaruh yang diberikan oleh kemampuan awal dan gaya belajar terhadap prestasi belajar kognitif merupakan pengaruh yang berdiri sendiri dan tidak berhubungan dengan media animasi dan modul interaktif.

Hal ini dapat disimpulkan bahwa tidak terdapat interaksi antara pembelajaran berbasis masalah melalui media animasi, modul interaktif, kemampuan awal dan gaya belajar terhadap prestasi kognitif siswa. 


\section{Kesimpulan Dan Rekomendasi}

\section{Kesimpulan}

Berdasarkan hasil penelitian ini dapat disimpulkan sebagai berikut:

1.Tidak ada pengaruh penggunaan media pembelajaran melalui animasi dan modul interaktif terhadap prestasi belajar fisika pada aspek kognitif khususnya pada materi suhu dan kalor.

2. Ada pengaruh Kemampuan awal tinggi dan rendah terhadap hasil prestasi kognitif siswa pada pokok bahasan suhu dan kalor.

3. Ada pengaruh Gaya belajar visual dan auditorial terhadap hasil prestasi kognitif pada pokok bahasan suhu dan kalor.

4. Tidak ada interaksi pengaruh antara pembelajaran berbasis masalah melalui media animasi dan modul interaktif dengan kemampuan awal terhadap prestasi belajar kognitif siswa.

5. Tidak ada interaksi pengaruh antara pembelajaran berbasis masalah melalui media animasi dan modul interaktif dengan gaya belajar terhadap prestasi belajar kognitif siswa.

6. Tidak ada interaksi pengaruh antara kemampuan awal dan gaya belajar terhadap prestasi belajar kognitif siswa.

7. Tidak ada interaksi pengaruh antara pembelajaran berbasis masalah melalui media animasi, modul interaktif, kemampuan awal dan gaya belajar terhadap prestasi kognitif siswa.

\section{Rekomendasi}

Hasil penelitian ini memberikan gambaran yang jelas tentang penerapan pembelajaran Fisika menggunakan metode problem based learning ditinjau dari kemampuan awal dan gaya belajar siswa pada materi pembelajaran Suhu dan Kalor.

Berdasarkan hasil penelitian maka diajukan beberapa rekomendasi sebagai berikut:

a. Guru dapat menggunakan metode problem based learning melalui media animasi maupun modul interaktif pada materi Suhu dan Kalor, karena kedua media ini dapat meningkatkan prestasi belajar siswa.

b. Kemampuan awal dan gaya belajar siswa memiliki pengaruh didalam peningkatan prestasi belajar siswa, sehingga guru perlu mengetahui kemampuan awal dan gaya belajar siswa sebelum menyampaikan materi pembelajaran Suhu dan Kalor.

\section{Daftar Pustaka}

Ahmad Abu Hamid. (2008). Penuntun Praktikum Kajian Fisika Sekolah. Yogyakarta: FMIPA UNY.

Anita Lie. (2007). Cooperative Learning. Jakarta : Grasindo.

Arief S Sardiman, dkk. (2003). Media pendidikan. Jakarta: Rajawali Pers.

Azhar Arsyad. (2009). Media Pembelajaran. Jakarta: Rajawali press.

BSNP. (2006). Panduan Penyusunan Kurikulum Tingkat Satuan Pendidikan jenjang Pendidikan Dasar dan Menengah. Jakarta: BSNP.

Budiyono. (2003). Metodologi Penelitian Pendidikan. Surakarta: UNS Press. (2009). Statistik Untuk Penelitian. Surakarta: UNS Press.

DePotter, B., Hernacki, M. (2008). Quantum Learning: Membiasakan Belajar Nyaman dan Menyenangkan. Bandung: Kaifa.

Diana Endah Handayani. (2011). Pembelajaran Fisika dengan Model Problem Based Learning Menggunakan CD Multimedia dan Modul Ditinjau dari Kemampuan Awal dan Aktivitas Belajar Siswa. Tesis. Surakarta: Program Pascasarjana Universitas Sebelas Maret.

Kukuh Santosa. (2002). Pemilihan dan Pengembangan Media Pembelajaran, Materi Pelatihan Penyusunan Design Pembelajaran Sekolah Menengah 
Umum Jawa Tengah. Semarang: DepDikNas

Kusuma Wardhani. (2011). Pembelajaran Fisika Dengan Model Problem Based Learning Menggunakan Multimedia dan Modul Ditinjau Dari Kemamuan Berpikir Abstrak dan Kemampuan Verbal Siswa. Tesis. Surakarta: Program Pascasarjana Universitas Sebelas Maret.

Maroebeni. (2008). Perkembangan Multimedia dan $\quad C D \quad$ Interaktif. http://maroebeni.wordpress.com/2008/1 1/05/perkembangan-multimedia-dancd-interaktif/\#comment-242. Diakses 25 April 2010.

Muhibin Syah . (2006). Psikologi Belajar. Jakarta: PT. Raja Grapindo Persada.

Mulyati Arifin, dkk. (2005). Strategi Belajar Mengajar Kimia. Malang: UM press.

Munandar, S.C.U. (2009). Pengembangan kreativitas anak berbakat. Jakarta: PT Rineka Cipta dan Dep. Pendidikan dan Kebudayaan.

Mustaqim. (2007). Pengaruh Pembelajaran Fisika Berbasis Masalah Dengan Metode Eksperimen Untuk Diskusi dan Demonstrasi Untuk Tanya Jawab Terhadap Prestasi Belajar Ditinjau Dari Kemampuan Awal Siswa Pada Pokok Bahasan Optik Geometri. Tesis. Surakarta: Program Pascasarjana Universitas Sebelas Maret.

Nana Sudjana. (2005). Media Pengajaran (Penggunaan dan Pembuatannya). Bandung: Sinar Baru Algensindo.

Oemar Hamalik. (2005). Kurikulum dan Pembelajaran. Jakarta: Bumi Aksara.

Purwanto Ngalim. (2007). Psikologi Pendidika. Bandung: Remaja Rosda Karya.

Rusman. (2010). Model-model Pembelajaran Mengembangkan Profesionalisme Guru. Jakarta: Rajawali Pers.

Santyasa Wayan I. (2008). Pembelajaran Berbasis Masalah dan Pembelajaran
Kooperatif. Makalah Disampaikan dalam Pelatihan Pembelajaran dan Asesmen Inovatif bagi Guru-guru Sekolah Menengah Kecamatan Nusa Penida, Bali, Tanggal 22 -24 Agustus 2008.

Supriyono,K.H. (2003). Common textbook (edisi revisi) strategi pembelajaran fisika. Malang: FMIPA Universitas Malang.

Susilana, Rudi. (2007). Media Pembelajaran. Bandung: CV Wacana Prima.

Sudaryono. (2007). Pengaruh Pembelajaran Fisika Berbasis Masalah Dengan Metode Demonstrasi dan Diskusi Terhadap Prestasi Belajar Siswa Ditinjau Dari Kemampuan Awal Siswa. Tesis. Surakarta: Program Pascasarjana Universitas Sebelas Maret.

Sugiyanto. (2009). Model-model Pembelajaran Inovatif. Surakarta: Mata Padi Presindo.

Suharsimi Arikunto. (2006). Prosedur Penelitian Suatu Pendekatan. Jakarta: Bumi aksara.

Tan, Ong-Seng. (2009). Problem Based Learning and Creativity. Singapore: Seng Lee Press.

Wina Sanjaya. (2007). Strategi Pembelajaran Berorientasi Standar Proses Pendidikan. Jakarta: Kencana.

Winkel, W.S. (1983). Psikologi Pendidikan dan Evaluasi Belajar. Jakarta: Gramedia.

Yatim Riyanto. (2009). Paradigma Baru Pembelajaran. Jakarta: Kencana Prenada. 